\title{
Preface: Marine and Lake Paleoseismology
}

\author{
E. Gràcia ${ }^{1}$, G. Lamarche ${ }^{2}$, H. Nelson ${ }^{3}$, and D. Pantosti ${ }^{4}$ \\ ${ }^{1}$ ICM-CSIC, Barcelona, Spain \\ ${ }^{2}$ NIWA, Wellington, New Zealand \\ ${ }^{3}$ IACT-CSIC, Granada, Spain \\ ${ }^{4}$ INGV, Rome, Italy \\ Correspondence to: E. Gràcia (egracia@icm.csic.es)
}

\begin{abstract}
This special issue of Natural Hazards and Earth System Sciences (NHESS) contains 16 papers that resulted from the European Science Foundation (ESF) Research Conference "Submarine Paleoseismology: The Offshore Search of Large Holocene Earthquakes" that was held at the Universitätszentrum Obergurgl (Austria), from 11 to 16 September 2010 (Pantosti et al., 2011). The conference enabled scientists from a number of existing lines of research to give an official start and international recognition to subaqueous paleoseismology.

The scope of this Special Issue is built on the content of the ESF conference and includes different aspects of marine and lake paleoseismology. The 16 papers are separated into two main groups, namely, on-fault or off-fault paleoseismic studies. On-fault paleoseismology focuses on the observation, measurement and quantification of history of movements along the fault plane, where direct evidence of earthquake activity includes displacement of sediment strata and landforms such as seafloor scarps (Argnani et al., 2012; Beck et al., 2012; Gràcia et al., 2012; Perea et al., 2012; Polonia et al., 2012). Off-fault paleoseismology uses the sedimentary record to identify deposits generated, directly or indirectly by seismic activity, such as mass-transport deposits, turbidites and tsunamites (Drab et al., 2012; Morey et al., 2013; Cattaneo et al., 2012; Gerardi et al., 2012; Goldfinger et al., 2013b; Langridge et al., 2012; Nelson et al., 2012; Patton et al., 2013; Pouderoux et al., 2012a; Smedile et al., 2012; Vacchi et al., 2012).
\end{abstract}

\section{Introduction}

Paleoseismology is the study of the geological records aiming at recognizing pre-historical earthquakes, identifying their origin and deriving the seismic potential of active faults (McCalpin, 2010; Wallace, 1981). Paleoseismology attempts to provide the physical parameters that quantify earthquake sources seismic potential, such as fault geometry, slip rate, recurrence period, displacement per event, and elapsed time since the last event (Pantosti and Yeats, 1993). These parameters are commonly used for seismic hazard evaluation in Cascadia, California and New Zealand (Barnes and Pondard, 2010; Goldfinger et al., 2003a; Stirling et al., 2012), where deformation rates are high, and where the paleoseismological studies are at the avant-garde. In these regions, paleoseismic studies have enabled great improvement of the hazard assessment (e.g. Goldfinger et al., 2012; Stirling et al., 2002; Wesnouky, 1999). The use of these techniques has also been used in zones with fast slipping faults (e.g. North Anatolian Fault, San Andreas Fault, Alpine Fault) and on slow moving faults (Crone et al., 1997; Masana et al., 2001; Vanneste and Verbeeck, 2001). In addition, underwater studies have shown a potential linkage of paleoseismic history between faster moving and slower moving faults (Goldfinger et al., 2008).

Paleoseismology is essential for modern seismic hazard assessment because it helps determine the seismic potential of seismogenic faults over much longer time periods than the instrumental measurements, historical catalogues or onshore paleoseismic records (Nelson et al., 2012). Paleoseismology studies are traditionally conducted onland from trenches (e.g. Berryman et al., 1998; Villamor and Berryman, 2001; Galli et al., 2008). This is now being developed and applied specifically to the marine environment, enlarging its potential use to highly populated coasts where the hazard associated with earthquakes and tsunamis produced by offshore faults is very high.

The methods used in marine and lake paleoseismology are multiscaled, multidisciplinary and use a variety of instrumental and sedimentological techniques. These methods have benefited from the rapid technological developments in seafloor and sub-seafloor imaging and sampling and have 


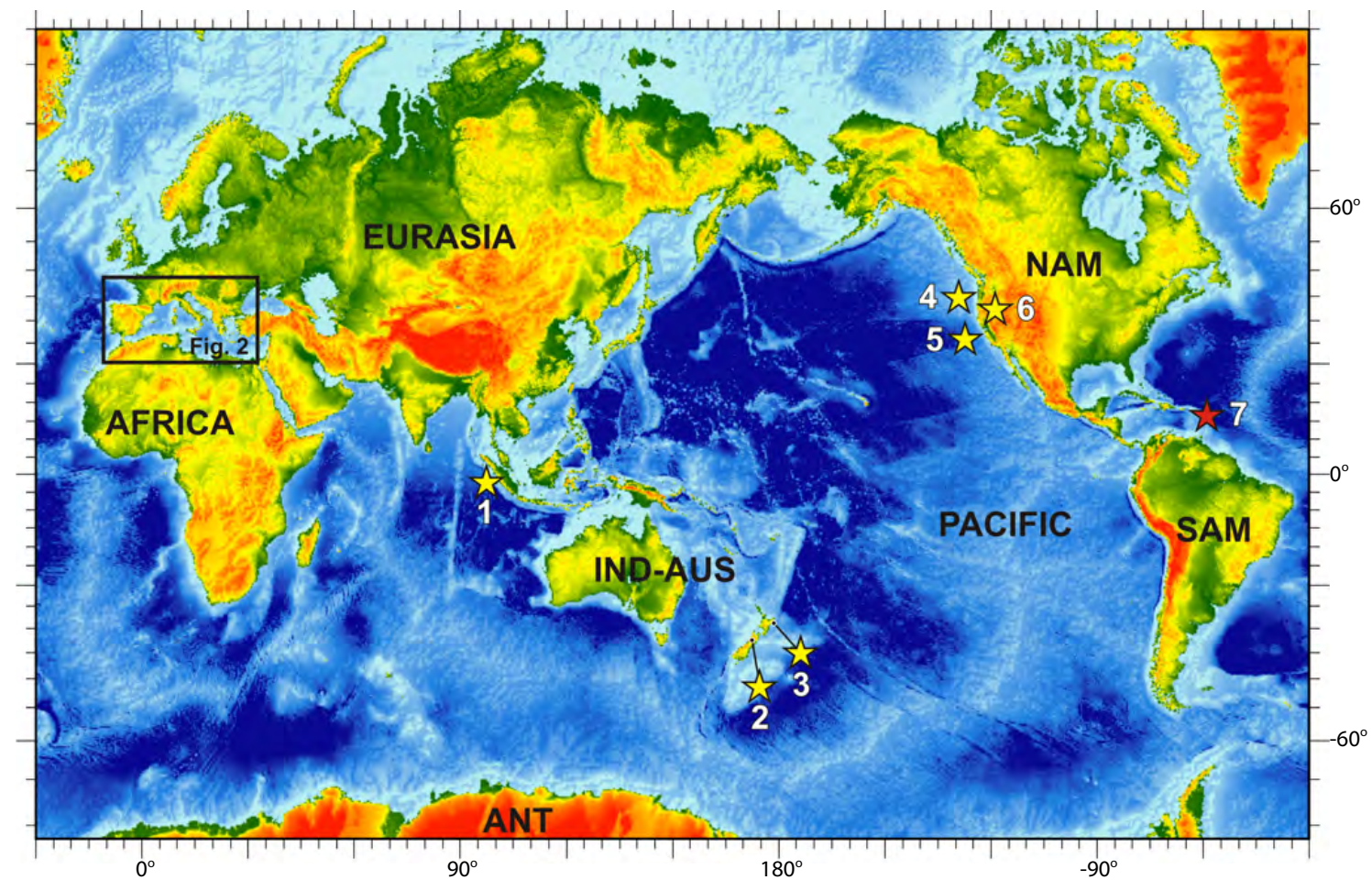

Fig. 1. Topographic and bathymetric world map with the location of all the study areas included in the articles of this Special Issue. Red stars correspond to on-fault paleoseismic studies and yellow stars to off-fault paleoseismic studies. (1) Sumatra subduction zone (Patton et al., 2013); (2) Lake Poerua, South Island, New Zealand (Langridge et al., 2012); (3) Poverty Bay in NE New Zealand (Pouderoux et al., 2012a); (4) Cascadia (Goldfinger et al., 2013b; Morey et al., 2013; Nelson et al., 2012; Patton et al., 2013); (5) northern California Margin (Nelson et al., 2012); (6) Cascade and Klamath mountains, West USA (Morey et al., 2013); (7) Lesser Antilles Arc (Beck et al., 2012). Black rectangle depicts location of Fig. 2. Main plates are located: ANT: Antarctic Plate; IND-AUS: Indo-Australian Plate; NAM: North America Plate; SAM: South America Plate.

resulted in vast improvement in the characterization of timing, location, and magnitude of pre-historical earthquakes that have occurred under water (at sea or in lakes).

The cases presented in this special issue are worldwide (Fig. 1), essentially along the fast moving $\left(>30 \mathrm{~mm} \mathrm{yr}^{-1}\right.$ ) subduction zones of the Antilles (Beck et al., 2012), Cascadia (Goldfinger et al., 2013b; Morey et al., 2013; Nelson et al., 2012; Patton et al., 2013), Sumatra (Patton et al., 2013), Hikurangi (Pouderoux et al., 2012a), and the transform faults of San Andreas in California (Nelson et al., 2012), Alpine Fault in New Zealand (Langridge et al., 2012) and Anatolian Fault in the Marmara Sea (Drab et al., 2012). Several cases describe paleoseismology of faults and associated tsunamis in the Mediterranean arc systems where slow $\left(<5 \mathrm{~mm} \mathrm{yr}^{-1}\right)$ plate convergence occurs (Argnani et al., 2012; Cattaneo et al., 2012; Gerardi et al., 2012; Gràcia et al., 2012; Perea et al., 2012; Polonia et al., 2012; Smedile et al., 2012; Vacchi et al., 2012) (Fig. 2). These studies demonstrate that marine and lake paleoseismology has an enormous potential to provide essential input to seismic and tsunami hazard assessments of coastal areas threatened by the effects of local and distant earthquakes.

\section{Underwater paleoseismology methods}

The survey methods in subaqueous paleoseismology are based both on traditional earthquake geology approaches developed inland and on the most advanced methodological and technological developments in marine geosciences, covering a wide range of resolutions. Acoustic mapping techniques identify geomorphic evidence of active faults and map fault traces along large areas relatively rapidly (Lamarche et al., 2006; Gràcia et al., 2003, 2006). The accuracy of most modern multibeam bathymetric systems is less than $10 \mathrm{~cm}$ when operated from a remotely operated vehicle (ROV) or an autonomous operated vehicle (AUV) (Armijo et al., 2005). Such accuracy is comparable to inland topographic surveys that map earthquake surface ruptures. Seismic imaging techniques detect the stratigraphic evidence of seismic activity, such as folded and truncated reflectors. When age control is obtained, this enables scientists to establish a temporal record of fault activity (Barnes and Pondard, 2010; Bull et al., 2006) over pre-historical and geological times. In shallow water depths, very high-frequency seismic reflection data now generate sub-seafloor resolutions similar to that achieved by trenching on land (i.e. sub-metres), thus en- 


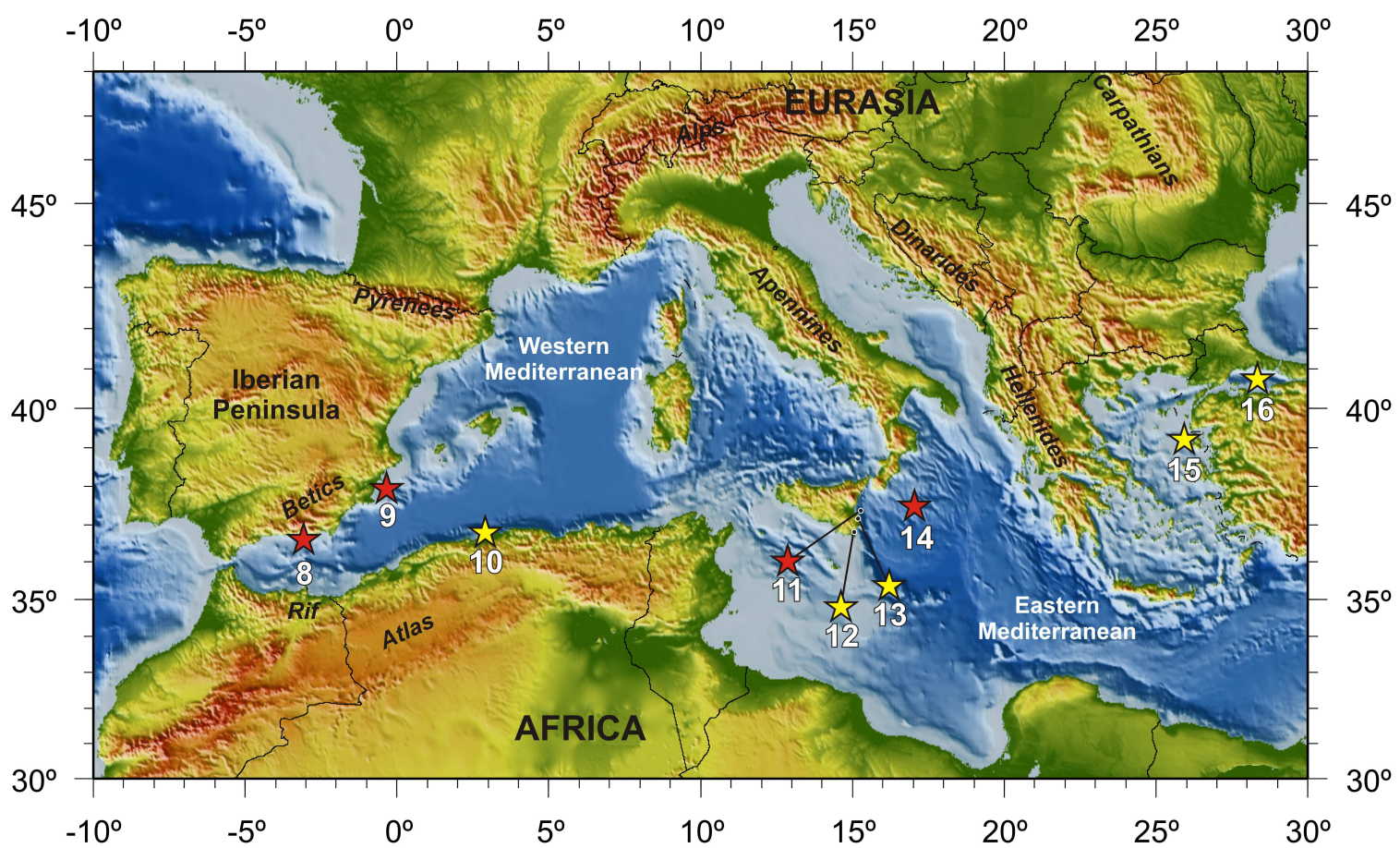

Fig. 2. Topographic and bathymetric map of the Mediterranean Sea with the location of areas studied in the articles of this Special Issue. Red stars correspond to on-fault paleoseismic studies and yellow stars to off-fault paleoseismic studies. (8) Adra Fault, NE Alboran Sea (Gràcia et al., 2012); (9) Bajo Segura Fault, western Mediterranean (Perea et al., 2012); (10) Central Algerian Margin (Cattaneo et al., 2012); (11) eastern Sicily (Argnani et al., 2012); (12) Pantano Morghella, SE Sicily (Gerardi et al., 2012); (13) Augusta Bay, eastern Sicily (Smedile et al., 2012); (14) Ionian Sea (Polonia et al., 2012); (15) Lesvos Island, NE Aegean Sea (Vacchi et al., 2012); (16) Marmara Sea (Drab et al., 2012). Main plates and mountain ranges are located.

abling the detection of the offset produced by a single event (Pondard and Barnes, 2010; Barnes and Pondard, 2010).

High-resolution geomorphic and stratigraphic approaches are applied in coastal areas both to pinpoint tsunami-related deposits and coseismic subsidence/uplift related to slip on a coastal or subaqueous fault.

Similarly to onland paleoseismology, dating is critical to constrain age models and to derive earthquake recurrence intervals. High-resolution accelerator mass spectrometer (AMS) radiocarbon ages is a widely used dating method in marine and lake environments (Goldfinger et al., 2013a; Goldfinger et al., 2013b; Langridge et al., 2012; Morey et al., 2013; Patton et al., 2013; Pouderoux et al., 2012a). Radiocarbon dating yields uncertainties, mainly due to the temporal and local variability of the reservoir age, and poor age calibration. Thus, it is important to minimize these uncertainties, lest errors are propagated throughout age models (e.g. Gutierrez Pastor et al., 2009). Date calibration and hemipelagic thickness together with accurate sedimentation rates help to reduce these radiocarbon age uncertainties and better constrain paleoseismic turbidite frequency data that are important for earthquake hazard analysis (Goldfinger et al., 2007; Gutierrez Pastor et al., 2009). Physical properties, mineralogic, biostratigraphic and geochemical signatures obtained through detailed sediment and petrological analyses also help to define new proxies for paleoearthquakes and to determine the origin of sediments disturbed by earthquakes, earthquake magnitudes, and correlation of paleoseismic events across wide geographical areas (Goldfinger et al., 2013b; Gràcia et al., 2010; Pouderoux et al., 2012b; Morey et al., 2013; Patton et al., 2013; Smedile et al., 2012).

Apart from the chiefly used radionuclides ${ }^{210} \mathrm{~Pb}$ and ${ }^{14} \mathrm{C}$ (Garcia-Orellana et al., 2006), paleomagnetic curves and oxygen isotopes are also being implemented to better constrain the age of sedimentary records (e.g. Moreno et al., 2002). Attempts at deriving seismic acceleration required to generate sediment failure are being developed from sediment pore pressure and geotechnical analysis (Lee et al., 2004; Pouderoux et al., 2013). In addition, modelling of underwater earthquake-generated processes, such as turbidity currents, has been attempted to better understand paleoseismic turbidite lithologic observations that relate to earthquake shaking and magnitude (Goldfinger, 2011; Nelson et al., 2012). Moreover, the integration of coastal tsunami effects (historical or pre-historical) and tsunami modelling contains a high potential for the definition of the highest hazard areas and to develop early-warning systems. 


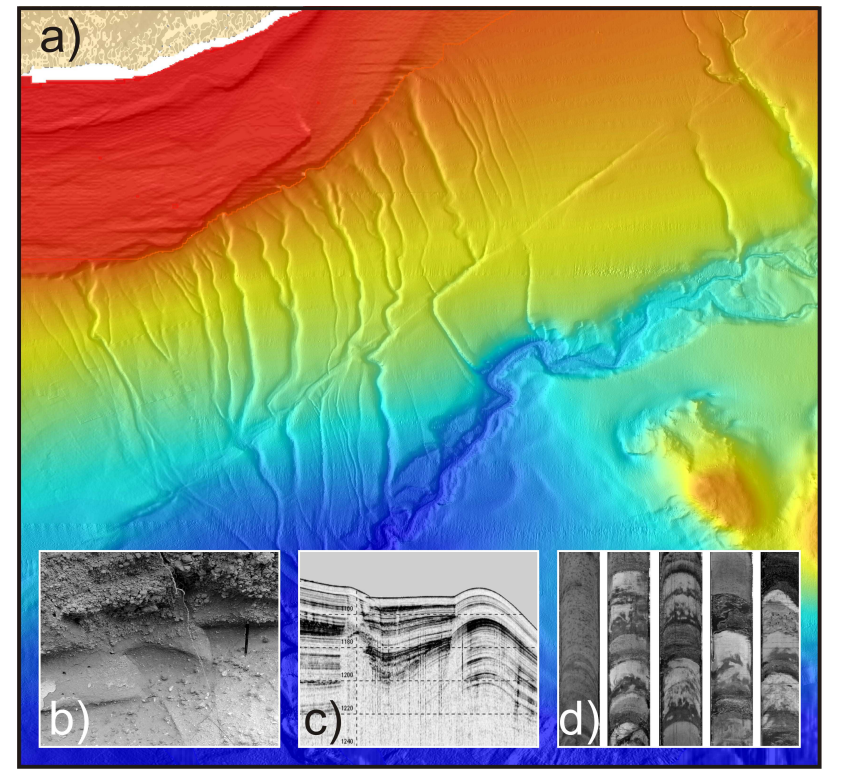

Fig. 3. Figure illustrating the different data and common methods used in marine and lake paleoseismology. (a) Colour shadedrelief bathymetric map; (b) Complementary data from outcrops and trenches onshore; (c) High-resolution marine seismic profile; (d) Deep-sea sediment core sections. See text for additional information.

\section{On-fault paleoseismology}

Fault morphology and geometry are well expressed underwater, both in map view (thanks to modern multibeam echosounder technology) and in cross section through seismic reflection profiling (Fig. 3). Fault morphology is well expressed in the marine environment as erosion is minimized and scarps are usually well developed (Gràcia et al., 2003, 2006; Polonia et al., 2004; Ridente et al., 2008). Examples of cross-cutting relationships can also be revealed in map view (e.g. offset channels for strike-slip faults) or in depth section (e.g. faulted horizons for dip-slip faults) (Fig. 3). Fault characterization (slip rate, length and kinematics) and identification of segment boundaries can be successfully imaged and characterized, although difficulties appear when dealing with slow-moving faults, great water depths and reactivated faults (Nodder et al., 2007; Bartolome et al., 2012; Polonia et al., 2012; Martínez-Loriente et al., 2013). In some locations, earthquake rupture segments can be identified, as in the Marmara Sea (Armijo et al., 2005) and vertical and strikeslip single displacements can be obtained as in New Zealand (Barnes and Pondard, 2010; Pondard and Barnes, 2010). Assigning historical and instrumental earthquakes to submarine faults may be difficult because earthquake location in oceanic areas is inherently associated with large uncertainties (Gràcia et al., 2012; Polonia et al., 2012).
Argnani et al. (2012) used numerical simulations to investigate the source of the large tsunami that hit eastern Sicily in 1693 and compute tide-gauge records along the coastline. A vivid debate exists among the scientific community on the possibility that the tsunami was generated by a submarine landslide or by the $M_{\mathrm{w}}=7.4$ earthquake fault. To contribute to this debate, the authors compare the values resulting from the simulation of the rupture of one of the NNWSSE-trending east-dipping extensional faults that according to the interpretation of seismic data is active in the nearSicilian offshore and the historical observations. These are in agreement in terms of wave polarity and location of strongest tsunami impact. The historical observations were also compared with the results of the simulation of a large-size submarine slide that was recognized on the footwall of the active fault. In this case there is no match; therefore, the tsunami is seen as the effect of the earthquake fault slip possibly with the contribution of the slide.

Polonia et al. (2012) analyze three tectonic features in the submerged portion of the Calabrian Arc, southern Italy, using deep seismic reflection data in an attempt to correlate them with destructive historical earthquakes. In correlating location, geometry and kinematics of these tectonic features, with the catalogue of historical earthquakes the authors were able to define causal relationships between the seismogenic features and specific historical events. In particular, they propose that the 1908 earthquake was triggered by the Messina Straits fault system while, the 1693 and 1169 earthquakes are likely related to the Malta STEP fault or splay fault systems.

Perea et al. (2012) investigate the offshore tectonic setting and recent activity of the Bajo Segura fault zone (BSFZ) in the Mediterranenan coast of Spain and its relations with the onshore structures. The analysis of 10 high-resolution singlechannel seismic sparker profiles allowed the reconstruction of the local seismo-stratigraphy and the mapping of the seafloor structures. This work has imaged the prolongation offshore of the Bajo Segura blind thrust fault and of the Torrevieja left-lateral strike-slip fault; one of these is proposed as the source for the 1829 Torrevieja earthquake. These new data highlight how the offshore survey of active regions integrated with on-land observation is critical to define potential seismic sources and thus represents a relevant contribution to the evaluation of the seismic hazard.

In their study, Gràcia et al. (2012) use swath-bathymetry and high-resolution seismic profiling together with sedimentological and age information from a sediment core to outline the $20 \mathrm{~km}$-length Adra Fault that is found offshore from Almería, Spain, in the northeast Alboran Sea (western Mediterranean). They show that seafloor sediment of Holocene age is offset, which indicates present-day tectonic activity. The location, dimension and kinematics of the $M_{\mathrm{w}}=6.11910$ Adra Earthquake suggest that the NW-SE trending normal dextral Adra Fault is the site of this earthquake. The fault seismic parameters indicate that the Adra Fault is a potential source of large magnitude $\left(M_{\mathrm{w}} \sim 6.5\right)$ 
earthquakes, which represent an unreported seismic hazard for the associated coastal areas.

Beck et al. (2012) performed a very high-resolution seismic reflection survey and some shallow piston coring to investigate late Quaternary to present faulting in the Lesser Antilles volcanic arc. Reworked sediment layers mostly in the hanging-wall of normal active faults and burying the fault scarps, along with their sedimentological characteristics are taken as evidence for instantaneous major sedimentary events triggered by earthquakes. The coseismic nature of these events was also verified integrating very highresolution seismic imagery and coring. By using sedimentation rates obtained by radionuclide activities, the most recent of these instantaneous deposits can be related either to the 1985 or to the 1974 earthquakes. Also, a 34 kyr-long seismic history at the Redonda system is reconstructed with the occurrence of five $M_{\mathrm{w}}>6$ events.

\section{Off-fault paleoseismology}

Off-fault studies most usually use seismically triggered landslides, turbidites and tsunamites to obtain information on earthquake locations and timing. These proxies are used to derive recurrence intervals of large magnitude earthquakes that are essential for seismic hazard assessment. However, the use of mass transport and sediment gravity flow deposits as paleoseismic indicators (or proxies) requires demonstrating that earthquakes are the most plausible triggering mechanism (e.g. Goldfinger et al., 2008, 2007, 2003b, 2012; Gràcia et al., 2010; Pouderoux et al., 2012a). Synchronicity tests provide such evidence. The test is based on coeval turbidites that can be correlated among widely separated depositional areas, at least during Holocene when the sea level stabilized, but sometimes up to the last glacial time $(18000 \mathrm{yr} \mathrm{BP})$ (Goldfinger et al., 2013b; Morey et al., 2013; Nelson et al., 2012; Pouderoux et al., 2012b). The selection of sampling sites is of key importance, as events may be missing or underrepresented depending on the depositional location (Goldfinger et al., 2012). Linking turbidite thickness and earthquake magnitude (and intensity) is not straightforward (Pouderoux et al., 2013), but has been demonstrated for Cascadia $M_{\mathrm{w}}=8-9$ earthquakes (Goldfinger et al., 2012; Nelson et al., 2012). Similar questions are posed by the interpretation of coastal or shallow water sediments layers as tsunamites. Also in this case, of key importance is the location of the sampling site and the definition of its geomorphic and dynamic evolution, the local climatic conditions, etc. (e.g. De Martini et al., 2010).

Off-fault paleoseismology papers in this special issue are grouped as thoses using turbidites and those using tsunami deposits as signatures of past earthquakes.

\subsection{Turbidites as signatures of past earthquakes}

The Pouderoux et al. (2012b) paper from the Hikurangi subduction margin of North Island New Zealand is unique because of its long Holocene and Pleistocene (18000 yr BP) turbidite paleoseismic record. Compositional, foraminiferal and geochemical signatures of the turbidites are used to characterise the sediment source area, the upper slope origin of the turbidity currents, and their dominant earthquake triggering mechanism (for $97 \%$ of the turbidites). An extensive tephrachronology record and OxCal calibrated AMS ${ }^{14} \mathrm{C}$ chronology identifies 73 correlated turbidites that have been synchronously triggered by earthquakes and have an earthquake mean return time of $230 \mathrm{yr}$.

In their study, Drab et al. (2012) combined the use of Xray imagery, XRF scanning and high-resolution granulometry performed on five cores to document the cyclicity of rupture along three segments of the North Anatolian Fault, in the Marmara Sea. This fault poses the greatest risk to the 12 million inhabitants of Istanbul (Turkey). A number of seismically triggered turbidites deposited in three adjacent basins are dated, and one turbidite event is interpreted as directly associated with the $M_{\mathrm{w}}=7.4,1912$ Mürefte earthquake.

Nelson et al. (2012) generate a record of large earthquakes $\left(M_{\mathrm{w}}=8\right)$ along the Cascadia subduction zone and the northern San Andreas Transform Fault from basin floors stratigraphy and turbidite lithology. Dating of turbidites, from radiometric ${ }^{14} \mathrm{C}$ ages, relative hemipelagic sediment thickness and sedimentation rates, enabled them to derive earthquake recurrence times. Their study also looks at the volumes and maximum run-out distances of material deposited on basin floors and the relationship with large earthquakes. Their interpretation states that seismo-turbidites generated from large earthquakes have characteristic lithologies, suggesting that earthquake shaking in multi-pulsed. synchronous triggering for stacked turbidites is imprinted in the lithology and that seismic strengthening of the sediment occurred along the margins. They conjecture that multipulsed and stacked turbidites are typically generated by a single large earthquake.

The Patton et al. (2013) paper evaluates turbidite deposition along slope and trench settings in two active subduction zones: Cascadia (NE Pacific Ocean) and Sumatra-Andaman (Indian Ocean). A total of 23 sediment cores are considered, and the methodologies include texture, physical properties, CT scans, XRF measurements, and ${ }^{137} \mathrm{Cs},{ }^{210} \mathrm{~Pb}$ and ${ }^{14} \mathrm{C}$ dating. Based on correlation of similar sequences of individual turbidites in different depositional settings, earthquakes are the main triggering mechanism for turbidite deposition along slope and trench settings of the Cascadia and SumatraAndaman margins during the Holocene. The authors discuss how sedimentation varies between sites, and how physical factors may influence turbidite sedimentation. Some aspects as source proximity, basin effects, turbidity current flow path, temporal and spatial earthquake rupture, hydrodynamics, and topography play a role in the deposition of the turbidites, as 
evidenced by the vertical structure of the final deposits. All these aspects are relevant to refine and improve the methodology of turbidite paleoseismology.

Goldfinger et al. (2013b) presents a comprehensive review of the marine and lake turbidite record along the Cascadia Margin, northwest USA. The authors draw inference on the origins of the turbidites using a range of sedimentological, petrological and geophysical methods and by correlating marine turbidites with onshore events observed in marshes and lakes. Overall, the turbidite sequence supports a model of segmented Cascadia margin earthquake ruptures limited to at least three segments. One Holocene turbidite on the northern margin may represent the sole segmented rupture and the authors suspect that three turbidites may represent the southern Cascadia earthquakes of 1873, 1980 and 1992.

The Morey et al. (2013) paper is important because it shows that the sedimentary record of inland lakes of the Cascade and Klamath mountains, as well as the offshore intraslope basins and multiple basin floor turbidite systems, have evidence for the same large Cascadia earthquakes. Deposits from these lakes contain inorganic terrigenous layers with similar ages, as well as comparable density and magnetic susceptibility signatures like those of the offshore paleoseismic turbidites (e.g. Goldfinger et al., 2013b; Nelson et al., 2012). The great distance and multiple depositional environments over which these events correlate, and the detailed analyses of deposit properties, suggest that Cascadia lakes also provide a paleoseismic record of large earthquakes in the Cascadia Subduction Zone.

Cattaneo et al. (2012) focuses on a set of seafloor features related to the 21 May 2003 Boumerdès earthquake $\left(M_{\mathrm{w}}=6.8\right)$ offshore central Algeria (western Mediterranean Sea). The earthquake triggered large turbidity currents responsible for numerous submarine cable breaks at the foot of the continental slope. Swath-bathymetry, acoustic backscatter, sidescan sonar mosaics complemented by sediment sampling and ${ }^{14} \mathrm{C}$ dating show the imprints of the 2003 event and of previous events, such as large slope scarps and erosional features on the continental slope, and turbidite beds alternating with hemipelagites in the distal basins. Preliminary dating results on a sediment core offshore Boumerdès show a $800 \mathrm{yr}$ interval between Holocene turbidites, in accordance with the estimated mean earthquake recurrence interval found on land.

\subsection{Tsunami deposits as signatures of past earthquakes}

The aim of the Vacchi et al. (2012) is to understand the depositional mechanism of clusters of large boulders ( $<17$ tons) consisting of beachrock slabs, and found on the southern coast of Lesvos Island in the northeast Aegean Sea (Eastern Mediterranean). To infer the origin of these boulder deposits (i.e. tsunami vs. storm wave), the authors follow an integrated methodology based on hydrodynamic equations together with geomorphological and seismotectonic data, ${ }^{14} \mathrm{C}$ dating, historical earthquakes and tsunami catalogues. Data analyses suggest that a recent tsunami is the most likely cause of boulder displacement, which may have been triggered either by the 1949 Chios-Karaburun earthquake $\left(M_{\mathrm{S}}=6.7\right)$ or by the 1956 Amorgos Island earthquake $\left(M_{\mathrm{S}}=7\right)$. These boulder deposits represent the first field evidence of tsunami wave impact in this sector of the Aegean Sea.

Gerardi et al. (2012) present the geological record of two tsunami inundations occurred in the large pond of Pantano Morghella, located in southeastern Sicily (west Ionian Sea). The infill of Pantano Morghella is dominated by fine-grained sedimentation although two anomalous sandy layers have been found at different depths, indicating the occurrence of high-energy marine inundations. Sedimentological and paleontological study of the deposits together with their spatial distribution provided evidence for tsunami inundations. Radiocarbon and optically stimulated luminescence (OSL) dating methods allowed the correlation between the age of the sandy layers and historical tsunamis. The younger deposit has been related with the 1908 Messina earthquake $\left(M_{\mathrm{w}}=7.1\right)$ near-source tsunami, whereas the flooding of the oldest event has been associated with a far, large source, the 365 AD Crete $\left(M_{\mathrm{w}}=8.3-8.5\right)$ earthquake.

The Smedile et al. (2012) study of the eastern shoreline of Sicily is important because it provides biostratigraphic criteria (micropaleontological; X-ray, physical properties, grain size, radiometric and tephra ages) to distinguish a $4000 \mathrm{yr}$ record of local onshore, far-generated, and shelf tsunami deposits from storm deposits. They show that the marine record of paleotsunamis is more complete than the inland one, because of continuous sedimentation and better preservation of stratigraphy in the offshore compared to coastal areas that are commonly affected by erosion, sedimentation and anthropic activities. This research indicates that the integration of geological and historical data can provide critical information regarding the extent and age of tsunamis of the past (e.g. inundation distance, age, and frequency) of immediate relevance for tsunami hazard assessment.

\subsection{Other elements as signatures of past earthquakes}

Langridge et al. (2012) provide one of the very few papers in this special issue that retrieved paleoseismicity data from a lake. This paper is also original in that the authors used drowned trees as well as more traditional alluvial fan samples retrieved in Lake Poerua to deduce the late Holocene history of the nearby Alpine Fault, New Zealand. The drowning of the trees and the generation of sediment fans are interpreted as originating from the damming of the lake subsequent three of the last four Alpine Fault earthquakes at ages ca. 1717,1615 or 1430 , and 1230 AD. Radiocarbon dating and an OxCal age model are used to support this interpretation. The discussion focusses on the need to insure good knowledge of the trees' response to drowning. 


\section{Important results of this NHESS Special Issue}

The papers of this issue show that the subaqueous environment has clear advantages for defining paleoseismological records compared to the terrestrial records. These are (i) marine sedimentation is generally continuous in time and space, allowing for regional stratigraphic correlations and for the reconstruction of a complete record of events; (ii) seafloor imaging and marine geophysical instrumentation allow us to explore (at different degrees of resolution) extensive areas in a relatively short time; (iii) offshore regions are essentially free of human modification and of large settlements that often disrupt the application of paleoseismology onshore; and (iv) underwater deposits contain much longer paleoseismic records compared to shoreline and onshore records that often are limited to the past $5000 \mathrm{yr} \mathrm{BP}$ of sea level highstand (e.g. Nelson et al., 2012; Pouderoux et al., 2012a, b).

This special issue shows the worldwide potential for defining paleoseismic history by utilizing state of the art techniques of underwater research. The numerous papers with extensive underwater paleoseismic records and with historical earthquake correlations indicate that active tectonic margins have turbidites that are dominantly triggered by earthquakes. The long underwater paleoseismic records, such as those of the Cascadia, California, and New Zealand margins, provide the important potential to discover critical superquake hazards, such as the Tohoku earthquake and resulting tsunami in Japan 2011 (Goldfinger et al., 2013b; Nelson et al., 2012; Pouderoux et al., 2012a, b). Although recent articles question the validity of turbidite paleoseismology (e.g. Sumner et al., 2013), this issue shows the worldwide applicability of on-fault and off-fault underwater paleoseismic research.

\section{Implications for future work and conclusions}

Today, subaqueous paleoseismology research benefits from the remarkable technological advancements that occurred during the past decade, were it be with respect with the tools of use in marine geosciences, the development in computer geoscience or the improvements in geochronology. All the papers in this special issue indicate that the subaqueous environment can provide seismogenic parameters required in seismic hazard assessment to a standard similar to or exceeding that of the terrestrial environment because of the longer underwater paleoseismic records. Unfortunately, one critical difference between onshore and offshore paleoseismology is the much higher costs of marine research. Yet underwater paleoseismic research can contribute significantly to improve earthquake hazards analyses in coastal regions and provide the information required by hundreds of thousands of people to be better prepared, thus enabling the saving of lives and enormous economic losses.
This special issue on Marine and Lake Paleoseismology demonstrates the value and importance of underwater research towards defining worldwide paleoseismic hazards. For on-fault paleoseismology, parameters describing the active fault characteristics, such as fault length, geometry (strike and dip), kinematics, complexity (segmentation) and slip-rate, can be estimated with a high level of confidence in the marine environment. Approaches used to derive information on individual paleoearthquakes, such as slip per event and age and thus, recurrence time and elapsed time, are still in the process of being strengthened and tested. However, the results presented in this special issue are promising and call for a common effort in this direction.

Another approach to evaluate the frequency and possibly the magnitude of earthquakes is based on off-fault studies. This approach, is based on more extensive research, both in marine and lacustrine environments, and thus, at present has provided the most complete underwater paleoseismic records. In addition, the extensive turbidite paleoseismological records have the potential to provide the most important hazards information about average and minimum recurrence times between large earthquakes, and where previously unknown superquakes might take place (e.g. Japan, 2011 in Goldfinger et al., 2013a). The problem here remains in the establishment of the correct relation of the observed effect to the causative process. Are the effects we observe all related to earthquake shaking? An answer can sometimes be obtained from the comparison with the historical seismic and tsunami records or through comparisons between onshore and offshore results. Potential in the understanding of the processes of emplacement of turbidites or mass transport deposits, and thus their causative mechanism, can be derived by establishing a pattern of synchroneity of correlative paleoseismic deposits along a margin, utilizing experimental modeling (e.g. Goldfinger, 2011) and also through numerical modeling. To establish the patterns of synchroneity requires extremely detailed sedimentologic and biostratigraphic research and expensive marine techniques.

The formalization of the approaches to use in Marine and Lake Paleoseismology and interpretations is the goal for the near future. There is also a need for setting the standards, so that results can be considered acceptable worldwide for input into seismic hazard assessment. To do so, a strong collaboration and exchanges are needed in the community, and test areas to advance different experiments should be commonly investigated.

Acknowledgements. We thank the European Science Foundation for having financially and logistically supported the Research (ESF) Conference "Submarine Paleoseismology: The Offshore Search of Large Holocene Earthquakes" that was held in Obergurgl in September 2010 and all the the scientists who participated in it. This article would not have been possible without funding from the Spanish Ministry of Science and Innovation (MICINN) through project SHAKE (CGL2011-30005-C02-02), the Catalan 
Government Generalitat de Catalunya through Grup de Recerca "Barcelona-Centre of Subsurface Imaging (B-CSI)" (2009 SGR 146, 2009-2013), the New Zealand Ministry of Business, Innovation and Employment (MBIE, previously Foundation for Research Science and Technology) through their program Paleoseismicity of the Alpine Fault and Hikurangi Margin (C01X0801), the EU TRANSFER project, and the Dipartimento della Protezione CivileIstituto Nazionale di Geofisica e Vulcanologia agreement for years 2007-2009. We are thankful to the reviewers for their helpful comments and suggestions on the individual manuscripts. Their efforts have improved the quality of this special issue on marine and lake paleoseismology. Finally, we express our gratitude to Fausto Guzzetti and Stefano Tinti (NHESS Editors) and Copernicus Publications for their collaboration and professional support.

We thank the reviewers (in alphabetical order) for their considerable work and the quality of their reviews for the issue: Flavio Anselmetti, Maria Serafina Barbano, Christian Beck, Andrea Billi, Namik Çağatay, Antonio Cattaneo, Gavin Dunbar, Nathalie Feuillet, Chris Goldfinger, Fausto Guzzetti, Richard Hiscott, José Jesús Martinez Diaz, Lisa McNeill, Alessandro Michetti, Neil Mitchell, Aron Meltzner, Alan Orpin, Raphäel Paris, E. Park, Jean-Noël Proust, Domenico Ridente, Anja Scheffers, Giovanni Scicchitano, and Stefano Tinti.

\section{References}

Argnani, A., Armigliato, A., Pagnoni, G., Zaniboni, F., Tinti, S., and Bonazzi, C.: Active tectonics along the submarine slope of south-eastern Sicily and the source of the 11 January 1693 earthquake and tsunami, Nat. Hazards Earth Syst. Sci., 12, 13111319, doi:10.5194/nhess-12-1311-2012, 2012.

Armijo, R., Pondard, N., Meyer, B., Uçarkus, G., de Lépinay, B. M., Malavieille, J., Dominguez, S., Gustcher, M.-A., Schmidt, S., Beck, C., Çagatay, N., Çakir, Z., Imren, C., Eris, K., Natalin, B., Özalaybey, S., Tolun, L., Lefèvre, I., Seeber, L., Gasperini, L., Rangin, C., Emre, O., and Sarikavak, K.: Submarine fault scarps in the Sea of Marmara pull-apart (North Anatolian Fault): Implications for seismic hazard in Istanbul, Geochem. Geophys. Geosyst., 6, Q06009, doi:10.1029/2004GC000896, 2005.

Barnes, P. M. and Pondard, N.: Derivation of direct on-fault submarine paleoearthquake records from high-resolution seismic reflection profiles: Wairau Fault, New Zealand, Geochem. Geophys. Geosyst., 11, Q11013, doi:10.1029/2010GC003254, 2010.

Bartolome, R., Gràcia, E., Stich, D., Martinez-Loriente, S., Klaeschen, D., Mancilla, F. L., Lo Iacono, C., Dañobeitia, J. J., and Zitellini, N.: Evidence for active strike-slip faulting along the Eurasia-Africa convergence zone: Implications for seismic hazard in the SW Iberian Margin, Geology, 40, 495-498, doi:10.1130/G33107.1, 2012.

Beck, C., Reyss, J.-L., Leclerc, F., Moreno, E., Feuillet, N., Barrier, L., Beauducel, F., Boudon, G., Clément, V., Deplus, C., Gallou, N., Lebrun, J.-F., Le Friant, A., Nercessian, A., Paterne, M., Pichot, T., and Vidal, C.: Identification of deep subaqueous coseismic scarps through specific coeval sedimentation in Lesser Antilles: implication for seismic hazard, Nat. Hazards Earth Syst. Sci., 12, 1755-1767, doi:10.5194/nhess-12-1755-2012, 2012.

Berryman, K. R., Beanland, S., and Wesnouky, S. G.: Paleoseismicity of the Rotoitipakau Fault Zone, a complex normal fault in the Taupo Volcanic Zone, New Zealand, New Zealand J. Geol. Geophys., 41, 449-465, 1998.

Bull, J. M., Barnes, P. M., Lamarche, G., Sanderson, D. J., Cowie, P. A., Taylor, S. K., and Dix, C. H.: High-Resolution Record of Displacement Accumulation on an Active Normal fault: Implications for Models of Slip Accumulation during Repeated Earthquakes, J. Struct. Geol., 28, 1146-1166, doi:10.1016/j.jsg.2006.03.006, 2006.

Cattaneo, A., Babonneau, N., Ratzov, G., Dan-Unterseh, G., Yelles, K., Bracène, R., Mercier de Lépinay, B., Boudiaf, A., and Déverchère, J.: Searching for the seafloor signature of the 21 May 2003 Boumerdès earthquake offshore central Algeria, Nat. Hazards Earth Syst. Sci., 12, 2159-2172, doi:10.5194/nhess-12-21592012, 2012.

Crone, A. J., Machette, M. N., and Bowman, J. R.: Episodic nature of eartquake activity in stable continental regions revealed by paleoseismicity studies of Australian and North American Quaternary faults, Australian J. Earth Sci., 44, 203-214, 1997.

De Martini, P. M., Barbano, M. S., Smedile, A., Gerardi, F., Pantosti, D., Del Carlo, P., and Pirrotta, C.: A unique 4000 yrs long geological record of multiple tsunami inundations in the Augusta Bay (eastern Sicily, Italy), Mar. Geol., 276, 42-57, doi:10.1016/j.margeo.2010.07.005, 2010.

Drab, L., Hubert Ferrari, A., Schmidt, S., and Martinez, P.: The earthquake sedimentary record in the western part of the Sea of Marmara, Turkey, Nat. Hazards Earth Syst. Sci., 12, 1235-1254, doi:10.5194/nhess-12-1235-2012, 2012.

Garcia-Orellana, J., Gràcia, E., Vizcaino, A., Masqué, P., Olid, C., Martínez Ruiz, F., Piñero, E., Sánchez-Cabeza, J. A., and Dañobeitia, J. J.: Identifying instrumental and historical earthquake records in the SW Iberian Margin using ${ }^{210} \mathrm{~Pb}$ turbidite chronology, Geophys. Res. Lett., 33, L24601, doi:10.1029/2006GL028417, 2006.

Gerardi, F., Smedile, A., Pirrotta, C., Barbano, M. S., De Martini, P. M., Pinzi, S., Gueli, A. M., Ristuccia, G. M., Stella, G., and Troja, S. O.: Geological record of tsunami inundations in Pantano Morghella (south-eastern Sicily) both from near and far-field sources, Nat. Hazards Earth Syst. Sci., 12, 1185-1200, doi:10.5194/nhess-12-1185-2012, 2012.

Goldfinger, C.: Possible turbidite record of earthquake source characteristics: a small scale test, NEHRP Annual Report, 34, Reston, VA, US Geological Survey, 18 pp., 2011.

Goldfinger, C., Nelson, C. H., and Johnson, J. E.: Deep-water turbidites as Holocene earthquake proxies: The Cascadia subduction zone and Northern San Andreas Fault systems, Ann. Geophys., 46, 1169-1194, 2003a.

Goldfinger, C., Nelson, C. H., and Johnson, J. E.: Holocene earthquake records from the Cascadia subduction zone and northern San Andreas fault based on precise dating of offshore turbidites, Ann. Rev. Earth Planet. Sc., 31, 555-577, 2003b.

Goldfinger, C., Morey, A. E., Nelson, C. H., Gutiérrez-Pastor, J., Johnson, J. E., Karabanov, E., Chaytor, J., and Eriksson, A.: Rupture lengths and temporal history of significant earthquakes on the offshore and north coast segments of the Northern San Andreas Fault based on turbidite stratigraphy, Earth Planet. Sci. Lett., 254, 9-27, 2007.

Goldfinger, C., Grijalva, K., Bürgmann, R., Morey, A. E., Johnson, J. E., Nelson, C. H., Gutiérrez-Pastor, J., Ericsson, A., Karabanov, E., Chaytor, J. D., Patton, J., and Gràcia, E.: Late 
Holocene Rupture of the Northern San Andreas Fault and Possible Stress Linkage to the Cascadia Subduction Zone, Bull. Seismol. Soc. Am., 98, 861-889, doi:10.1785/0120060411, 2008.

Goldfinger, C., Nelson, C. H., Morey, A. E., Johnson, J. E., Patton, J., Karabanov, E., Gutiérrez-Pastor, J., Eriksson, A. T., Gràcia, E., Dunhill, G., Enkin, R. J., Dallimore, A., and Vallier, T.: Turbidite event history - Methods and implications for Holocene paleoseismicity of the Cascadia subduction zone, in: US Geological Survey Professional Paper 1661-F, US Geological Survey, Reston, VA, 332, 2012.

Goldfinger, C., Ikeda, Y., Yeats, R. S., and Ren, J.: Superquakes and Supercycles, Seismological Res. Lett., 84, 24-32, doi:10.1785/0220110135, 2013a.

Goldfinger, C., Morey, A. E., Black, B., Beeson, J., Nelson, C. H., and Patton, J.: Spatially limited mud turbidites on the Cascadia margin: segmented earthquake ruptures?, Nat. Hazards Earth Syst. Sci., 13, 2109-2146, doi:10.5194/nhess-13-21092013, 2013b.

Gràcia, E., Danobeitia, J., Vergès, J., and PARSIFAL Team: Mapping active faults offshore Portugal (36N-38N): Implications for seismic hazard assessment along the southwest Iberian margin, Geology, 31, 83-86, 2003.

Gràcia, E., Pallàs, R., Soto, J. I., Comas, M., Moreno, X., Masana, E., Santanach, P., Diez, S., García, M., Dañobeitia, J., and HITS scientific party: Active faulting offshore SE Spain (Alboran Sea): Implications for earthquake hazard assessment in the Southern Iberian Margin, Earth Planet. Sci. Lett., 241, 734-749, doi:10.1016/j.eps1.2005.11.009, 2006.

Gràcia, E., Vizcaino, A., Escutia, C., Asioli, A., Rodés, A., Pallàs, R., Garcia-Orellana, J., Lebreiro, S., and Goldfinger, C.: Holocene earthquake record offshore Portugal (SW Iberia): testing turbidite paleoseismology in a slowconvergence margin, Quaternary Sci. Rev., 29, 1156-1172, doi:10.1016/j.quascirev.2010.01.010, 2010.

Gràcia, E., Bartolome, R., Lo Iacono, C., Moreno, X., Stich, D., Martínez-Diaz, J. J., Bozzano, G., Martínez-Loriente, S., Perea, H., Diez, S., Masana, E., Dañobeitia, J. J., Tello, O., Sanz, J. L., Carreño, E., and EVENT-SHELF Team: Acoustic and seismic imaging of the Adra Fault (NE Alboran Sea): in search of the source of the 1910 Adra earthquake, Nat. Hazards Earth Syst. Sci., 12, 3255-3267, doi:10.5194/nhess-12-3255-2012, 2012.

Gutierrez Pastor, J., Nelson, C. H., Goldfinger, C., Johnson, J. E., Escutia, C., Eriksson, A., Morey, A., and The Shipboard Scientific Party: Earthquake control of Holocene turbidite frequency confirmed by hemipelagic sedimentation chronology on the Cascadia and northern California active continental margins, in: SEPM, Special Publication, edited by: Kneller, B., McCaffrey, W., and Martinsen, O. J., 179-197, 2009.

Lamarche, G., Barnes, P. M., and Bull, J. M.: Faulting and Extension Rate over the last 20,000 Years in the Offshore Whakatane Graben, New Zealand Continental Shelf, Tectonics, 25, TC4005, doi:10.1029/2005TC001886, 2006.

Langridge, R. M., Basili, R., Basher, L., and Wells, A. P.: Late Holocene landscape change history related to the Alpine Fault determined from drowned forests in Lake Poerua, Westland, New Zealand, Nat. Hazards Earth Syst. Sci., 12, 2051-2064, doi:10.5194/nhess-12-2051-2012, 2012.

Lee, H. J., Orzech, K., Locat, J., Konrad, J. M., and Boulanger, E.: Seismic strengthening, a conditioning factor influencing subma- rine landslide development, 57th Canadian Geotechnical Conference, 8-14, CD-ROM, 2004,

Martínez-Loriente, S., Gràcia, E., Bartolome, R., Sallarès, V., Connors, C., Perea, H., Lo Iacono, C., Klaeschen, D., Terrinha, P., Dañobeitia, J. J., and Zitellini, N.: Active deformation in old oceanic lithosphere and significance for earthquake hazard: Seismic imaging of the Coral Patch Ridge area and neighboring abyssal plains (SW Iberian Margin), Geochem. Geophys. Geosyst., 14, 1-26, doi:10.1002/ggge.20173, 2013.

Masana, E., Villamarín, J. A., and Santanach, P.: Paleoseismic results form multiple trenching analysis along a silent fault: The El Camp Fault (Tarragona, northeastern Iberian Peninsula), Acta Geologica Hispanica, 36, 329-354, 2001.

McCalpin, J.: Paleoseismology, Academic Press cop., San Diego, 2010.

Moreno, E., Thouveny, N., Delanghe, D., McCave, I. N., and Shackleton, N. J.: Climatic and oceanographic changes in the Northeast Atlantic reflected by magnetic properties of sediments deposited on the Portuguese Margin during the last $340 \mathrm{Ka}$, Earth Planet. Sci. Lett., 202, 465-480, 2002.

Morey, A. E., Goldfinger, C., Briles, C. E., Gavin, D. G., Colombaroli, D., and Kusler, J. E.: Are great Cascadia earthquakes recorded in the sedimentary records from small forearc lakes?, Nat. Hazards Earth Syst. Sci., 13, 2441-2463, doi:10.5194/nhess-13-2441-2013, 2013.

Nelson, C. H., Gutiérrez Pastor, J., Goldfinger, C., and Escutia, C.: Great earthquakes along the Western United States continental margin: implications for hazards, stratigraphy and turbidite lithology, Nat. Hazards Earth Syst. Sci., 12, 3191-3208, doi:10.5194/nhess-12-3191-2012, 2012.

Nodder, S. D., Lamarche, G., Proust, J.-N., and Stirling, M. W.: Characterizing earthquake recurrence parameters for offshore faults in the low strain, compressional Kapiti-Manawatu Fault System, New Zealand., J. Geophys. Res-Solid Earth, 112, B12102, doi:10.1029/2007JB005019, 2007.

Pantosti, D. and Yeats, R. S.: Paleoseismology of great earthquakes of the late Holocene, Annali di Geofisica, XXXVI, 237-257, 1993.

Pantosti, D., Gràcia, E., and Nelson, C. H.: Searching for Records of Past Earthquakes Under Water, EOS, 92, p. 48, 2011

Patton, J. R., Goldfinger, C., Morey, A. E., Romsos, C., Black, B., Djadjadihardja, Y., and Udrekh: Seismoturbidite record as preserved at core sites at the Cascadia and Sumatra-Andaman subduction zones, Nat. Hazards Earth Syst. Sci., 13, 833-867, doi:10.5194/nhess-13-833-2013, 2013.

Perea, H., Gràcia, E., Alfaro, P., Bartolome, R., Lo Iacono, C., Moreno, X., Masana, E., and EVENT-SHELF Team: Quaternary active tectonic structures in the offshore Bajo Segura basin (SE Iberian Peninsula - Mediterranean Sea), Nat. Hazards Earth Syst. Sci., 12, 3151-3168, doi:10.5194/nhess-12-3151-2012, 2012.

Polonia, A., Gasperini, L., Amorosi, A., Bonatti, E., Bortoluzzi, G., Çagatay, N., Capotondi, L., Cormier, M.-H., Gorur, N., McHugh, C., and Seeber, L.: Holocene slip rate of the North Anatolian Fault beneath the Sea of Marmara, Earth Planet. Sci. Lett., 227, 411-426, 2004.

Polonia, A., Torelli, L., Gasperini, L., and Mussoni, P.: Active faults and historical earthquakes in the Messina Straits area (Ionian Sea), Nat. Hazards Earth Syst. Sci., 12, 2311-2328, doi:10.5194/nhess-12-2311-2012, 2012. 
Pondard, N. and Barnes, P. M.: Structure and paleoearthquake records of active submarine faults, Cook Strait, New Zealand: Implications for fault interactions, stress loading, and seismic hazard, J. Geophys. Res-Solid Earth, 115, B12320, doi:10.1029/2010JB007781, 2010.

Pouderoux, H., Lamarche, G., and Proust, J.-N.: Building an 18 000-year-long paleo-earthquake record from detailed deep-sea turbidite characterisation in Poverty Bay, New Zealand, Nat. Hazards Earth Syst. Sci., 12, 2077-2101, doi:10.5194/nhess-122077-2012, 2012a.

Pouderoux, H., Proust, J.-N., Lamarche, G., Orpin, A., and Neil, H.: Postglacial (after $18 \mathrm{ka}$ ) deep-sea sedimentation along the Hikurangi subduction margin (New Zealand): Characterisation, timing and origin of turbidites, Mar. Geol., 295-298, 51-76, doi:10.1016/j.margeo.2011.11.002, 2012b.

Pouderoux, H., Proust, J.-N., and Lamarche, G.: Submarine paleoseismology of the northern Hikurangi subduction margin of New Zealand as deduced from turbidite record since 16ka, Quaternary Sci. Rev., doi:10.1016/j.quascirev.2013.11.015, in press, 2013.

Ridente, D., Fracassi, U., Di Bucci, D., Trincardi, F., and Valensise, G.: Middle Pleistocene to Holocene activity of the Gondola Fault Zone (Southern Adriatic Foreland): Deformation of a regional shear zone and seismotectonic implications, Tectonophysics, 453, 110-121, doi:10.1016/j.tecto.2007.05.009, 2008.

Smedile, A., De Martini, P. M., and Pantosti, D.: Combining inland and offshore paleotsunamis evidence: the Augusta Bay (eastern Sicily, Italy) case study, Nat. Hazards Earth Syst. Sci., 12, 25572567, doi:10.5194/nhess-12-2557-2012, 2012.

Stirling, M. W., McVerry, G. H., and Berryman, K. R.: A new seismic hazard model of New Zealand, Bull. Seismol. Soc. Am., 92, 1878-1903, 2002.
Stirling, M. W., McVerry, G., Gerstenberger, M., Litchfield, N. J., Van Dissen, R. J., Berryman, K. R., Barnes, P. M., Wallace, L., Villamor, P., Langridge, R., Lamarche, G., Nodder, S., Reyners, M., Bradley, B., Rhoades, D., Smith, W., Nicol, A., Pettinga, J., Clark, K., and Jacobs, K.: National Seismic Hazard Model for New Zealand: 2010 update, Bull. Seismol. Soc. Am., 102, 15141542, doi:10.1785/0120110170, 2012.

Sumner, E. J., Siti, M. I., McNeill, L. C., Talling, P. J., Henstock, T. J., Wynn, R. B., Djajadihardja, Y. S., and Permana, H.: Can turbidites be used to reconstruct a paleoearthquake record for the central Sumatran margin?, Geology, 81, 763-766, doi:10.1130/g34298.1, 2013.

Vacchi, M., Rovere, A., Zouros, N., and Firpo, M.: Assessing enigmatic boulder deposits in NE Aegean Sea: importance of historical sources as tool to support hydrodynamic equations, Nat. Hazards Earth Syst. Sci., 12, 1109-1118, doi:10.5194/nhess-121109-2012, 2012.

Vanneste, K. and Verbeeck, K.: Paleoseismological analysis of the Rurrand Fault near Julich, Roer Valley Graben, Germany; coseismic or aseismic faulting history?, Evaluation of the potential for large earthquakes in regions of present day low seismic activity in Europe, edited by: Camelbeeck, T., Galadini, F., Meghraoui, M., van-der-Berg, M., Geologie en Mijnbouw, Netherlands Journal of Geosciences, 80, 155-169, 2001.

Villamor, P. and Berryman, K. R.: A late Quaternary extension rate in the Taupo Volcanic Zone, New Zealand, derived from fault slip data, New Zealand J. Geol. Geophys., 44, 243-269, 2001.

Wallace, R. E.: Active faults, paleoseismology and earthquake hazards in the western United States, in Earthquake prediction: An international review, edited by: Simpson, D. W. and Richards, T. G., 209-216, Am. Geophys. Un., Washington, 1981.

Wesnouky, S. G.: Crustal deformation processes and the stability of the Gutenberg-Richter relationship, Bull. Seismol. Soc. Am., 89, 1131-1137, 1999. 